\title{
Passive Design, Urban-Rural Architectural Morphology for Subtropics
}

\author{
By Asma Khalid ${ }^{1}$
}

\begin{abstract}
Built environment is a function of man-made setting, surroundings, conditions which is the center of human activity in architectural places. The integration of nature into the built environment determines the urban or the rural form of settlements. The present research aims to specify architectural morphology of sub-tropical region through a case analysis of the situation in Pakistan. The field study analyses the existing housing stock in Pakistan, in urban settings and as a result of vernacular traditions in the villages. The paper identifies the regional characteristic behaviour of highland, lowland, coastal and arid region. It gives an overview of the current urban housing situation in Pakistan. It discusses the type of housing unit, the occupant behaviour, lifestyle of the people, It also identifies the pattern of energy used within the residential buildings of Pakistan. The architectural planning in urban and rural regions, their long term passive design techniques to cope with the climate challenges of a particular area have been discussed in detail. The paper recommend some contextual and adapted passive features of vernacular architecture in urban houses.
\end{abstract}

Keywords: Architectural-morphology, Urban, Housing, Vernacular, Passive Design, Built Environment

\section{Introduction}

Worldwide energy consumption has resulted in the depletion of natural resources, climate change, global warming and have increased the environmental concerns. Urban heat has affected the quality of life. Mitigation strategies are needed to meet new challenges of urban island effect (1). According to Energy Information Administration (EIA, 2015), residential sector is second highest end user energy consumption from last two decades (2). The increased use of appliances in urban areas with regards to the income and ownership of households are raising the worldwide energy demand (3). There are empirical studies (4,5) that associates urban and rural design in terms of sustainability, its emerging technologies, cultural diversities, challenges and oportunities. Housing research make an inevitable connection with time and space that can be linked in built environment of urban and rural settlements. Population influx has posed sustainable urban environment challenges for many Asian countries like Pakistan. The architects and planners in their specific realm are finding standardised solution to the environmental and health concerns. The criteria of EU standards and IPCC demand the thermal comfort solutions of building design using passive measures, materials and techniques. The zero energy building and low carbon footprint of recent construction can help to meet the current building construction challenges, environmental and health standards.

Population growth, urbanization and industrialization have also adversely affected the 
housing situation in Pakistan. Over 40 million additional people are expected to live in towns and cities of Pakistan by 2025 (6). Due to the failure of various urban development plans, the major cities have grown in haphazard patterns, exacerbating environmental degradation. The national housing policy lacks the energy conservation policies and guidelines for the housing sector in Pakistan. The careful positioning of dwelling, street orientation, land scape design, land use and spatial design should be done according to the climatic conditions. Unfortunately, the growth of cities is unplanned, and haphazard. The city development concept is based on land usage for built structure. There is not much space left for open areas. Additionally cities have become warmer due to incorrect choices of building materials, and the least consideration of the passive design techniques in architectural development. The concepts of orientation, appropriate street width, and provision of open spaces or landscape areas have not been given a deliberate thought. The existence of bylaws has also been violated in many old and new housing colonies.

According to the 1998 census, the total number of housing units, throughout the country amounted to 19.3 million with a share of $67.7 \%$ rural and $32.3 \%$ in urban areas. The overall housing stock comprised of $39 \%$ mud houses, $40 \%$ semi-brick houses and $21 \%$ brick houses. The average household size is 6.6 persons and the occupancy per room is 3.3 persons (7). Urban and rural housing in most cities of Pakistan is scattered, unplanned clustered based on small town and village. The center of these villages and town are densely populated and extends in various directions as necessity driven. The urban environment is unplanned and small communities gathered to form Mohallas. Due to the introduction of various city development authorities for various cities in Pakistan, some town and areas have planned or semi planned settlements in the form of societies. Majorly three types of street patterns exist in urban settlements of Lahore: Geometric regularity (Model Town), Rectilinear patterns (Cantonments), and maze-like, winding, twisting (Walled City) streets. In urban cities of Pakistan, various development authorities exist for the preparation and regularization of the residential building bylaws. For example, the capital city "Islamabad" is administered by the Capital Development Authority (CDA), Lahore by the Lahore Development Authority (LDA), Multan by Multan Development Authority (MDA), along with the other cities bodies. These bodies approve all the developmental projects for the cities. Similarly, for almost every city, there exists a controlling authority to regularize the construction. But specifically regarding the development of energy efficient codes and standards for residential buildings in Pakistan, no document exists so far. The existing energy provisions are designed to fulfil the requirements of more than 3 stories high-end domestic and commercial buildings. It clearly states "The future development of Energy Provisions, 2011 shall encompass low-end users and buildings, if deemed necessary up to $10 \mathrm{KW}$ and / or of appropriate covered area (8)."

\section{Architectural Morphology}

In order to address the said challenges of building and environment, there is a need to understand the architectural morphology of an area. The Architectural morphology is the evolutionary study of variation in the built environment. It explains 
the shift of various approaches in architectural typologies, urban and rural, modern and vernacular. The categorical study of change in building is looked upon according to geographically position, infrastructure provision, and cultural character of building. The paper is an attempt to understand and differentiate the rural vernacular architecture and urbanization with the aim to improve the passive design approach through architectural morphology. It will also give an overview of the current housing situation and passively analyzed architectural and environmental challenges in both rural and urban areas.

\section{Objectives}

The objective of the research is to review the architectural morphology of urban and rural areas of Pakistan in sub-tropical regions for the identification of best practices. The paper identifies practically implemented climate responsive passive design choices in high, lowland, coastal and arid regions. The novelty of the research is to look contextually for the vernacular approaches in Pakistan. It will also discuss the urban housing situation, the pattern of energy consumption in urban houses, their architectural details, ventilation strategies and thermal design of envelope components. The research aims to recognize passive features of rural area successfully adapted into urban living. These passive features common in both urban and rural areas will help to improve energy efficiency and reduced environmental impact in the future design of buildings.

\section{Methodology}

The paper uses a comparative case study approach, based on field visits and non-structured interviews with the local community. The methodological approach helps in identifying the resilient features in terms of locally available materials, construction practices, passive design features and technological application in modern and vernacular houses. The current study helps to identify and analyze the potential benefits of these resilient features as observed during the field visits without numerical modelling. In order to cover the diverse range application of various practical approaches, both urban and rural climate settings of subtropical regions were evaluated. Firstly the cultural and climatic contexts of various regions were identified as vernacular traditions in building practices are the result of weather conditions prevalent in those areas. The field visit was based on collecting information for various passive strategies for highland, lowland, coastal, and arid climate. The domestic architecture in rural houses helps in identifying climate responsive practices for each zone. The selection of few cities in each zone represents the traditional prevalent practices. All representative cities of four zones are moderately developed in facilities and infrastructure development. The layout design of houses and passive design approaches of these regions are point of major discussion. The next half of the paper describes morphological practices in urban houses. The research assess the sterotype approach used in the urban culture using industrialized building materials and with various passive methods. This has been facilitated collecting architectural plans from regional and municipal planning development authorities. It also reviews the energy practices in building, residential energy consumption, associated passive design issues and thermal comfort solutions. 


\section{Subtropics}

Subtropics are defined as geographic and climate zones located between the tropics and temperate zones. Worldwide geographic region having subtropical climates includes Pakistan, Moroco, Iran, Nepal, Bangladesh, Afghanistan part of Austraila, india, China, Vietnam highland, continental United States, Argentina and South Africa etc. Figure 1 shows the countries that come in subtropic zones, north and south of the Equator.

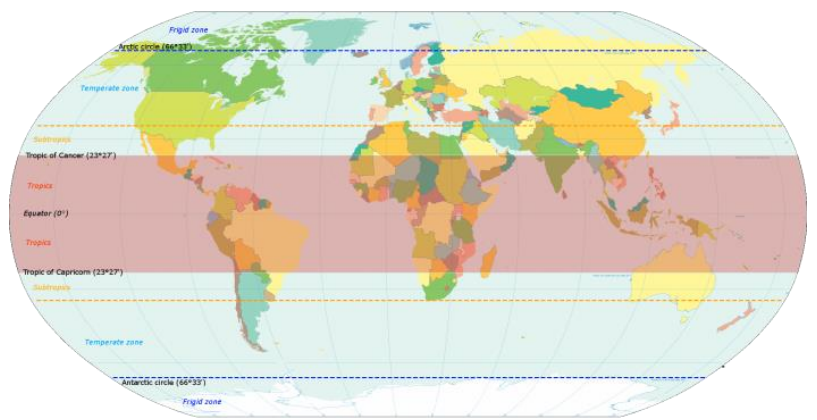

Figure 1: Subtropic region on world map

The Subtropical climates are often characterized by hot summers and mild winters with occasional frost. Generically, the Subtropic topography is divided into Highland climate, Lowland climate, Coastal climate and Arid. However, this generic classification does not represent the variation of climatic parameters (temperature, rainfall, and humidity, etc.) But can surely be taken as a baseline for further study.

\section{Limitation of Research}

The research potentially identifies the architectural morphology of subtropic climate with a major emphasis on Pakistan. The broader results can be generalized to subtropical regions but a large variance in climate, cultural and architectural morphology exists in subtropic regions of other countries. So the characteristics of subtropic climate and topography has been discussed in detail with reference to Pakistan only.

\section{Vernacular Houses}

Pakistan is strategically located approximately between $24-37^{\circ} \mathrm{N}$ latitudes and $62-75^{\circ} \mathrm{E}$ longitudes in the western zone of south Asia. The region is blessed with vast natural resources, diverse climate and geographic conditions of plains, deserts, forests, hills, and plateau. In order to understand the Physiographic of Pakistan, geographic and climatic conditions will help in identifying suitable passive design traditions in rural housing. 


\subsection{Highland climate and domestic architecture}

The climate of highland zone is characterized by prolonged cool to cold winters, with relatively short mild to warm summer. The northern region experiences rainfall throughout the year, while the western part receives less rainfall. The region includes the major areas of Gilgit, Chitral, Sakardu, Swat, Peshawar, Kohat, Waziristan, Quetta, Sibi and Kalat etc.

Dense pine forest encourages the use of timber as construction material in many houses of swat valley. The decoration, carving and the intricate detailing on the exterior and interior is reflection of artistic values of local craftsmanship. Similar type of locally available traditional materials like stone, timber, mud bricks, clay and soil mortar are used in Gilgit Baltistan houses. These houses are the perfect blend of stone craftsmanship; each stone was chiselled to shape, meticulously graded for the required size. The roof is flat, projected porches serve to fulfil the purpose of sun spaces. The distinctive feature of local domestic architecture, is interior passages with low doorways.

Hunza valley traditional houses uses Bhatar (a Pashto word) cross wooden beams structure as vernacular construction techniques. The interlaced structural system will act as an overhang in upper storeys (9). The wood being locally available material is conventionally used in houses. High quality wood is seasoned before use in construction to increase building life. The wide spread technique of treating wood through preservatives is missing in old and new construction. Additionally these areas are more prone to natural disaster. Domestic rural houses are made of large pieces of stones, with rubble masonry, stone chips and mixture of lime mortar with egg yolk. It has been proven that the use of egg albumen increases the strength of mortar (10). The housing colony in Hunza is 400 years old, tightly packed houses with a courtyard in the centre and interconnected spaces through verandas. Village houses in the highland zone are closely packed and interconnected in a way that their roof become approachable and villagers can walk across on the top. In some cases, the flat roof construction well shaded through sun spaces helps to minimize the harsh effect of cold weather especially in winters. Use of skylight with an openable lid, Roshandan, and stair hall light ways are the most attractive feature of these houses, increases the light in interior spaces. The low roof leads to stepped terraces providing landscape opportunities.

Figure 2: Highland Roof

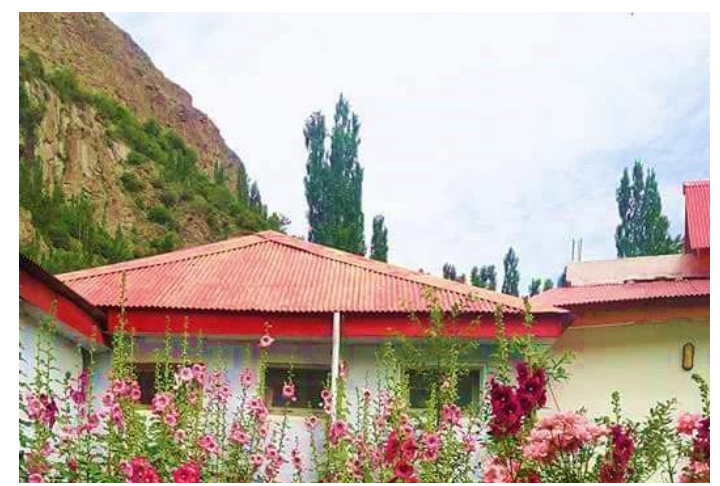


Figure 3: Village Houses, Hunza
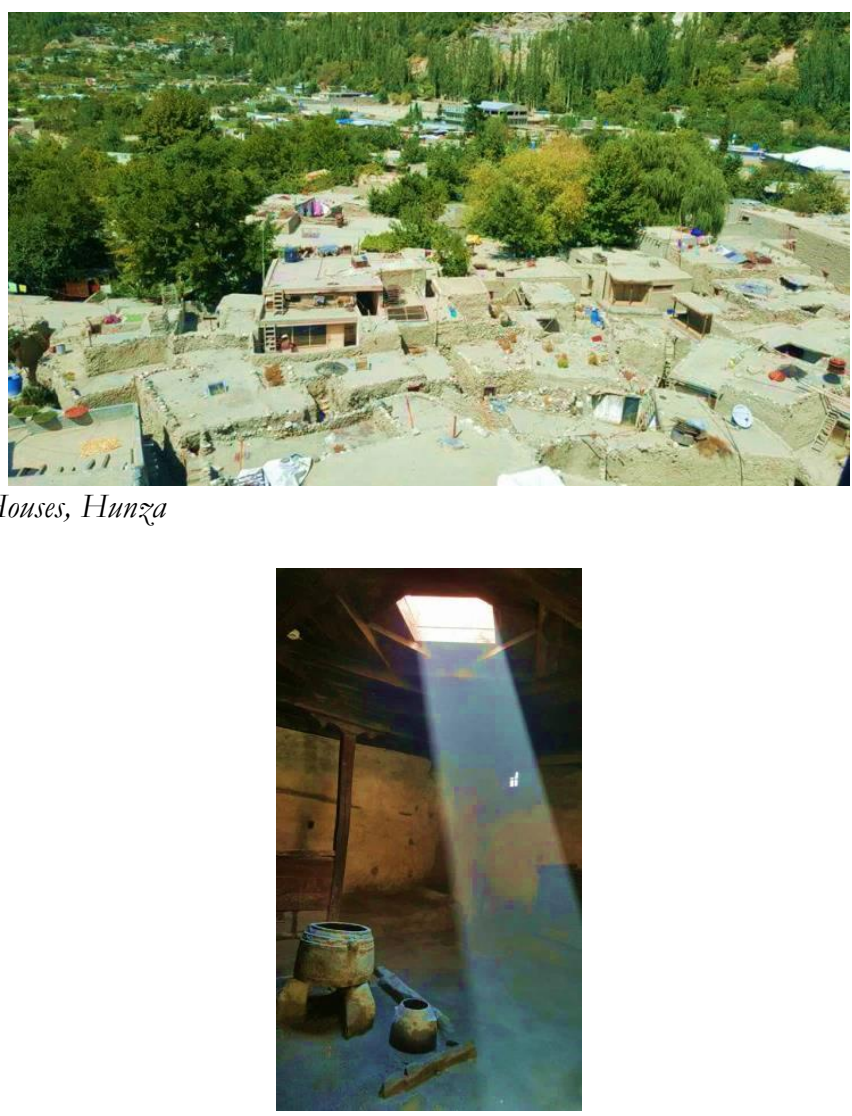

Figure 4: Skylight

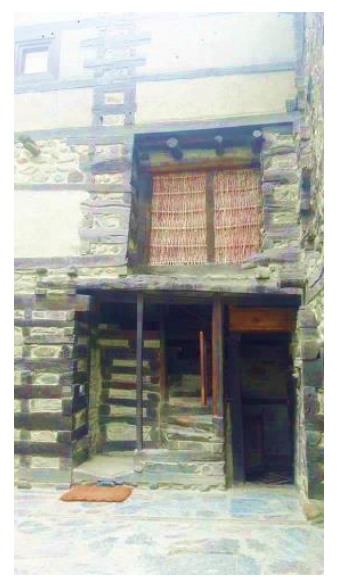

Figure 5: Shaded Entrance 
Figure 6: Stepped Terrace

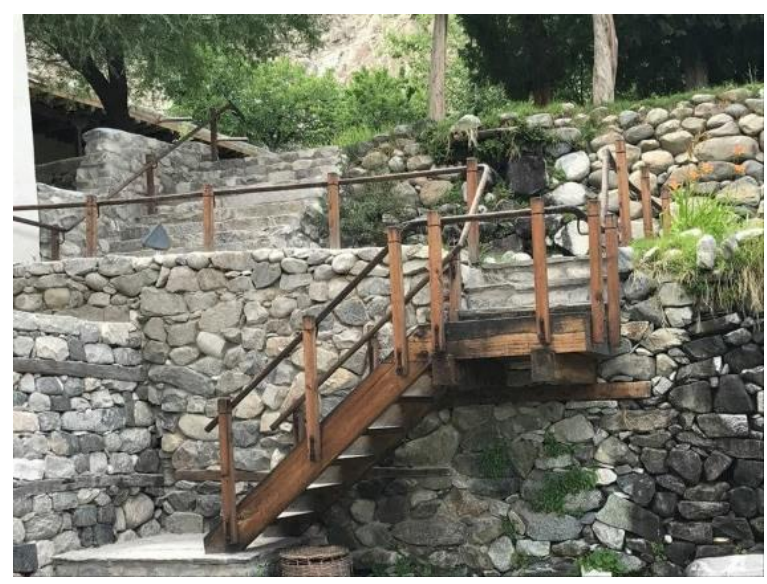

The domestic architecture of Balochistan is dominated by the tribal cultural traditions reflected in houses and other building form. The fortified compounds and houses have several courtyards and verandas as symbol of passive architecture and social unification place. In mountain regions, the domestic architecture has high massive stone walls with portholes. These portholes are round windows with a hinged, watertight glass cover in the side of a vessel for admitting air and light.

Figure 7: Bhatar construction
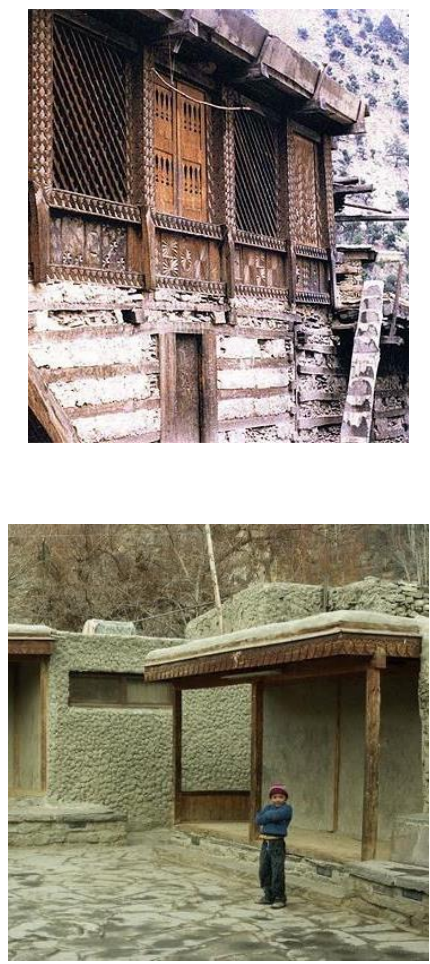

Figure 8: Stone Rubble Masonry 
Figure 9: Shaded Verandah

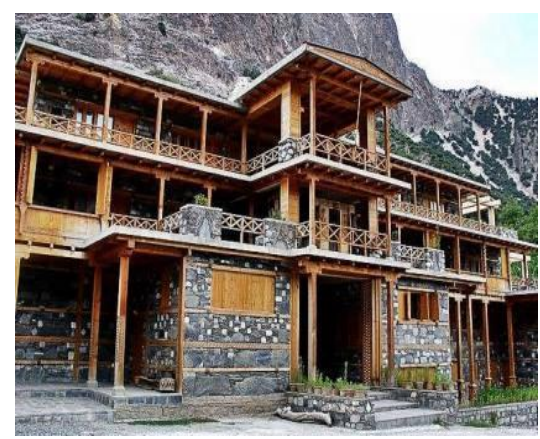

The use of palm trees in southern region of domestic structure is prevalent, that form the pitch of roof as structural elements with earthen layer. The spacious courtyard with covered verandas are the traditional feature of these houses, increase the air flow within the house.

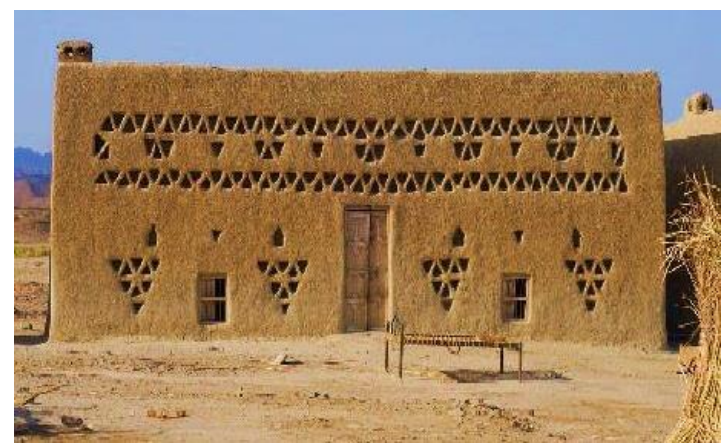

Figure 10: Village house of Balouchistan, reflection of Pattan culture

Mud houses, with traditional Balochi design are also found in warmer regions. These houses have low height wooden openings. The provision of chimney at one corner of pyrapid wall helps to create air flow current and also acts as smoke removal for better indoor air quality. There is a large open space at front of houses used for outdoor sleeping in summer and social gathering in winters.

The dry plateau of Balouch region is reflection of Gidan to Baluch and Kodal to Pattan culture. The domestic architecture of rural houses in mountainous region have the thatched roofs with elongated dome (11). The earth sheltered houses found in the foothill and valleys of mountain near Peshawar are blended with nature as urban planning follows the topographic hills.

\subsection{Lowland climate and domestic architecture}

The low land climate has hot summers, with monsoon rainfall and cool winters. The land is mostly arid in southern upper and lower Indus Plain. The thunder storms are also common in northern region of Indus. It includes major cities like Islamabad, Lahore, Faisalabad, Multan, Jacobabad, Shikarpur, etc. 
In rural houses, the use of earthen materials like moulded mud or clay blocks, pise, sun dried and burnt bricks, kankar, white lime mortar and plaster, terracotta tiles, sheesham and neem wood are the available construction materials in rural houses of northern and southern upper Indus plain. It is the plastic quality of mud and clay that rural people make different pattern on interior and exterior of walls. The provision of shelves, niches and cupboard facilitates the display and storage. Mud and clay is also carved in detailed traditional and cultural patterns. The screens and Jalies just above the door lintel level and below the roof will help to draft natural flow of air. People profoundly design these traditional patterns to show their neighbours, fulfilling the psychological and aesthetical needs of occupants. The wooden openings and thick mud plastered walls increase the time lag of walls to the inside space. The floor of houses made of composite material, using earth mixed with water and straw or dung. The presence of organic material acts as binder and its thermal conductivity also increases.

The old fashioned Punjabi houses have wooden windows with iron bars in checkers form. The windows are outlines with paint for aesthetic reason. Sometime, the elongated ventilators are provided in rooms for ventilation that eliminates the provision or use of sill level windows. The ventilators have screen geometric pattern in various shapes with small holes at different intervals for air passage.

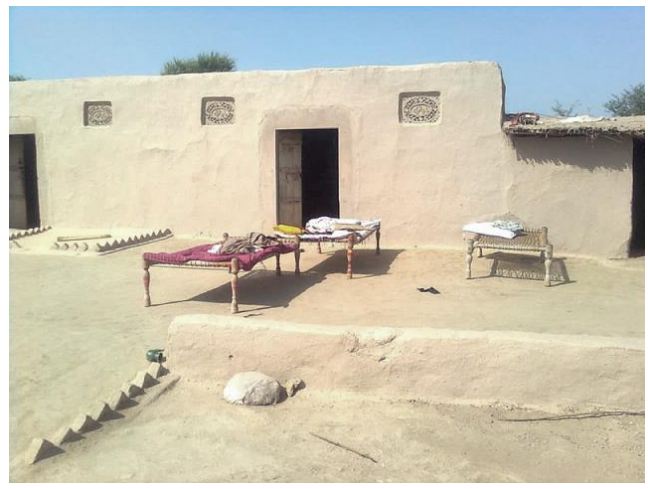

Figure 11: Outdoor Sleeping

Figure 12: Mud Brick Construction

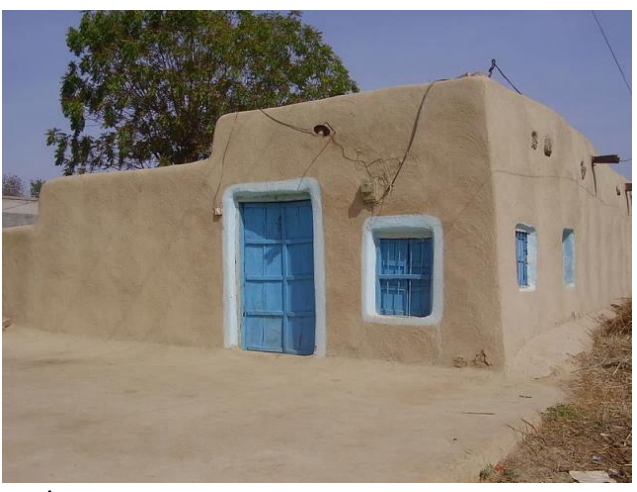


The roofs of Pakka houses in urban and rural settlements of Punjab have column beam structure. The roof of walled city houses in Punjab is tied using wood griders placed at regular distance and reinforced with brick tiles. In some houses, reinforced concrete construction is prevalent, constructed using timber shuttering with a layer of 6-9 inch thick layer of a mixture of lime, cement and sand plaster is spread over the roof. Over this layer, mud-straw mixture is applied, making the roof almost one foot thick. Walls and roof are painted with white washed and acts as reflective material for summer heat. Another traditional material is the use of an internal finish red, lime plaster called surkhi and pukka kalli, to keep the internal surface cool. The craftsmanship is mastered by some old masons, with wide variety of intricate wall design.

Baithak1 and Mehmann khana are the places of social gathering or common sitting for the social interaction in early morning and evening of summer and during mid noon in winters. They are open yard with trees as shelter, occupying with charpaies. The Bathak in the rural houses are peripheral enclosure that serves the same purpose of guest sitting, commonly observed in the old houses of walled city. The concept was furthered adopted in modern houses for porches as extended shading of roof.

\subsection{Coastal climate and housing architecture}

The coastal climate is characterized by moderate temperature in summer and winters. The provision of sea breeze maintains a maritime effect throughout the years. The land near the sea heats up and cools down quickly, whereas sea water heats up and cools down slowly results in high humidity conditions. The region comprises Indus delta, Karachi, and Makran coast. The culturally diverse region gained importance in British times, marked with the existence of many bungalows and real estate buildings.

The old architecture in the region ideally deals with high humidity and warmer summer temperature. The vernacular houses are characterized by high ceiling design for increased air current. In most rural areas, domestic structures of lower Indus delta have roofs with central ridge, and double slope. These thatched roof forms the hedge like construction of closely packed juniper stems (11). Mud and cement sand block are used as construction and finishing material for wall, roof and floors.

In many village houses of coastal region, dwellings are constructed with Acacia and Sheesham timber frames to form structural support and is plastered with straw and earth, collected from Indus delta. This vernacular traditions help in keeping the envelope cool and enhances the natural cross ventilation through large openings. In traditional houses, projected balconies provide protection from solar radiations and casting long shadows. Wooden, concrete and terracotta lattices increase the indoor comfort when air pass through the narrow holes of screens, improving the air quality and reduces air temperature.

${ }^{1}$ Baithak is a drawing room used for social gatherings. 
Figure 13: Thatched Roof
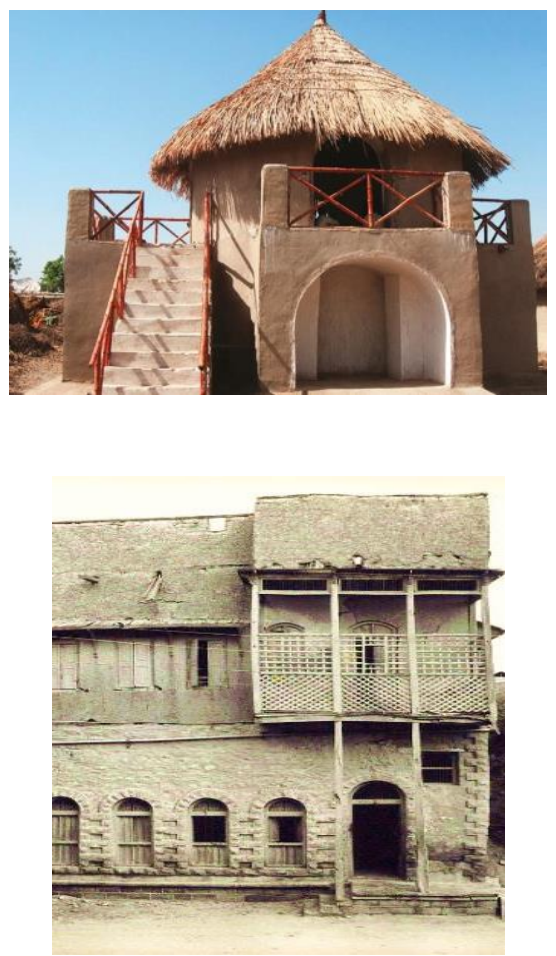

Figure 14: Shaded Verandas

The wind catchers of Hyderabad are the wind chimneys, traditionally known as badkhor / Manghu dominating the skyline of the ancient city. The south west prevailing winds enter the house through the top triangular structure, covered by wood, or plastered metal sheet. The chimney is kept open to take advantage of night time breezes in summer and daytime hot air in winter vice versa.
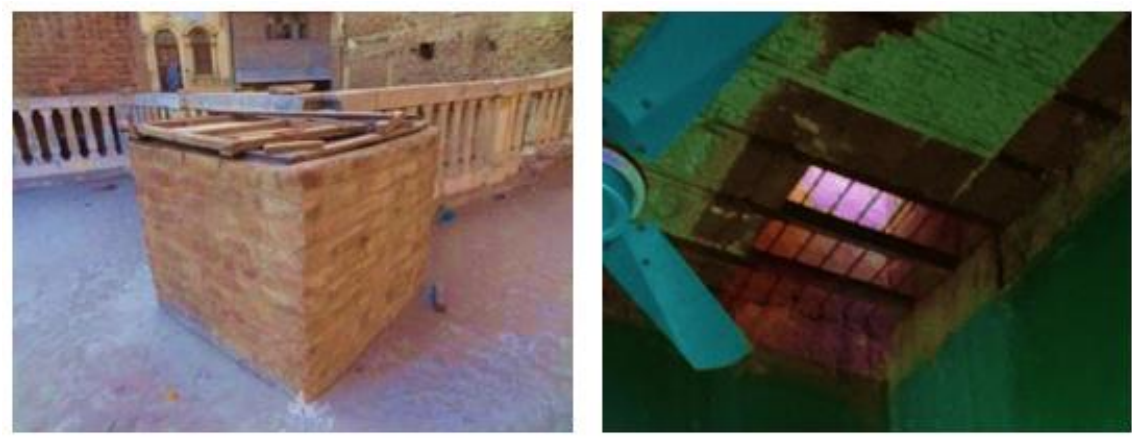

Figure 15: Wind Chimney for cross ventilation

Unfortunately, this vernacular cooling technique has been largely replaced by air conditioning and other mechanical means in modern times. 


\subsection{Arid Climate and housing architecture}

Tharparkar is an arid region in the south-eastern province of Sindh, Pakistan. Tharparkar area has desert and barren region of the sand dunes covered with thorny bushes (12). The material availability in close vicinity of Nagarparkar hills contains Granite rocks and crystalline rocks of the Arravelli range (13). The vernacular houses of region have hut style room with thatched roofs of thick straw or reed supported by beams. The walls are also made of sun dried bricks also plastered with mud finish. The conical shaped thatched roof is known as Chaunras that extends on huts openings for rain protection. These wooden frame windows and doors are kept for passage way. In flat roof construction, windowless interior increases the air flow from roof top. The presence of roof with fixed ventilators attracts south-west breeze in internal space (Figure 16).

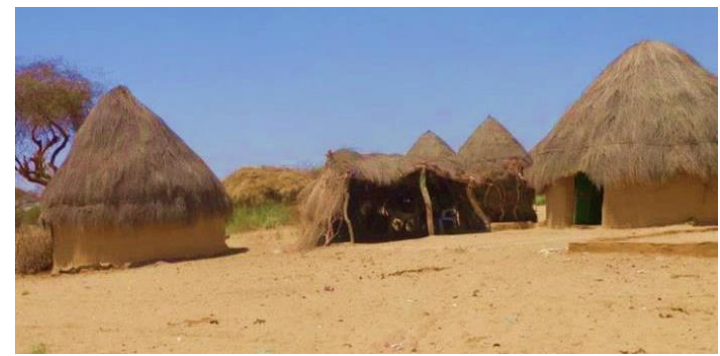

Figure 16: Conical shaped Chaunras

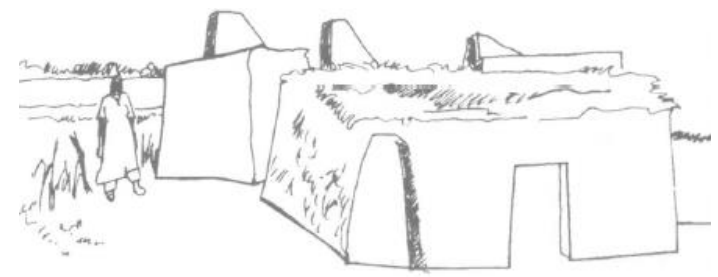

Figure 17: Tharparkar House

The landscape beauty is further enhanced by ditches, traditional ponds and wells, which collect rain water. These dwellings have water storage on roof top with solid borders. Another type of construction known as Pucca houses made from stone and timber.

\section{Urban houses in Pakistan}

Urban house in metropolitan cities have with modern industrialized materials and construction technologies. There are different types of housing units exist in Pakistan. The design, construction, and choice of materials vary according to locality. The urban houses are categorized in "marla" 2 or "kanal"3 on the basis of plot area. The classification is mainly based on following area requirements as shown in Table 1.

2 In Punjab, land is measured in marlas; one marla is equal to roughly 30 square meters.

320 marla is equals to $1 \mathrm{kanal}$, with covered area $400 \mathrm{~m} 2$ 
Table 1: Plot size distribution based on area

\begin{tabular}{|c|l|c|}
\hline Number & Plot size & Maximum assigned area in $\mathrm{m}^{2}$ \\
\hline 1 & Less than or equal to 5 Marlas & $80-120$ \\
\hline 2 & Less than or equal to 10 Marlas & $120-220$ \\
\hline 3 & Less than or equal to 20 Marlas or 1 Kanal & $220-420$ \\
\hline 4 & More than 1 Kanal & Above 420 \\
\hline
\end{tabular}

\subsection{Energy consumption of a residential building}

It is estimated that approximately $35 \%$ of total national electricity consumption is accounted for by the buildings sector. Domestic buildings and houses account for approx. $85 \%$ of this consumption. (14). Improved building design can reduce energy bills of houses by $20 \%$ and this figure can be raised to $50 \%$ by use of efficient appliances (15). The electricity consumption of a typical Pakistani house is largely dependent on the covered area and the number of households.

Table 2: Description of energy consumption variables

\begin{tabular}{|c|c|c|c|c|c|c|c|}
\hline \multirow{2}{*}{ No } & \multicolumn{2}{|c|}{ Plot area } & $\begin{array}{c}\text { Covered } \\
\text { area }\end{array}$ & $\begin{array}{c}\text { Conditioned } \\
\text { space }\end{array}$ & Minimum & Maximum & \multirow{2}{*}{ No. of persons } \\
\cline { 2 - 7 } & Marla & $\mathrm{m}^{2}$ & $\mathrm{~m}^{2}$ & $\mathrm{~m}^{2}$ & \multicolumn{2}{|c|}{$\begin{array}{r}\text { Electricity consumption) } \\
\text { KWh }\end{array}$} & \\
\hline 1 & 5 & 105 & 95 & $12-24$ & 100 & 684 & \multirow{2}{*}{$6-12$} \\
\hline 2 & 10 & 211 & 167 & $16-54$ & 250 & 1000 & \\
\hline 3 & 20 & 418 & 367 & $48-85$ & 450 & 3000 & \\
\hline
\end{tabular}

The Table 2 shows the varying conditioned space requirement for given three types of houses. It also defines the maximum and minimum annual electricity consumption range. It is worth mentioning that the space heating requirements in domestic housing are met by gas and coal. These fuels serve as cheaper sources for heating as compared to electricity.

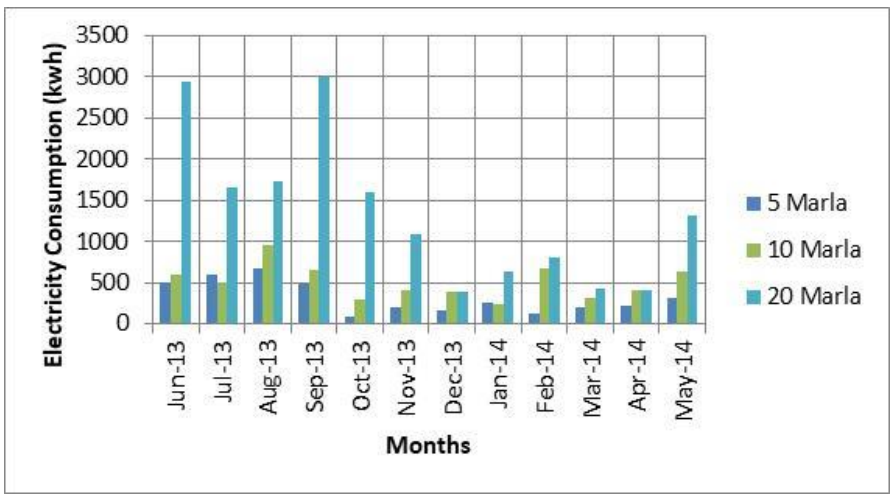

Figure 18: Monthly Electricity consumption in urban houses, Pakistan

Figure 18 shows the electricity consumption in typical Pakistani houses with three different plot sizes belonging to the middle income group. It can be seen that the 
electricity consumption is higher in summer and the cooling need extends for six months from May to October. The conditioned space requirements vary and are dependent on the covered plot area and the number of households. The energy consumption is defined by the occupancy pattern and their scheduled hours spent at home. The number of occupants in an urban house varies between 4 to 10 persons with the exception of bigger families up to 15 people in joint family system. However the number reduces during the day or business hours as most households are at their workplaces and maximum energy loads experiences during the evening, night and on weekends.

\subsection{Architectural morphology of urban houses}

The residential buildings are either single, double or triple stories distributed in the particular areas in clusters of colonies, and societies. The building configuration is either square or rectangular. The main entrance connected to a lobby or foyer is mostly located in the center, giving access to the semi-private and public spaces. In some residential units, the main entrance directly opens into a courtyard space. The communal or social spaces are typically classified as public spaces of house, including drawing, dinning, powder room and guest room.

In some residential units, a separate toilet or outhouse may be located in the courtyard some distance away from the living space. Small plots less than 3 marlas $(60-80 \mathrm{~m} 2)$ do not have any bylaws and space utilization is the most important consideration for stakeholders. The residential units having area greater than $105 \mathrm{~m} 2$ are mostly constructed in accordance with bylaws. Open spaces are left on the front, back and side and the percentage of covered area varies depending on the plot size.
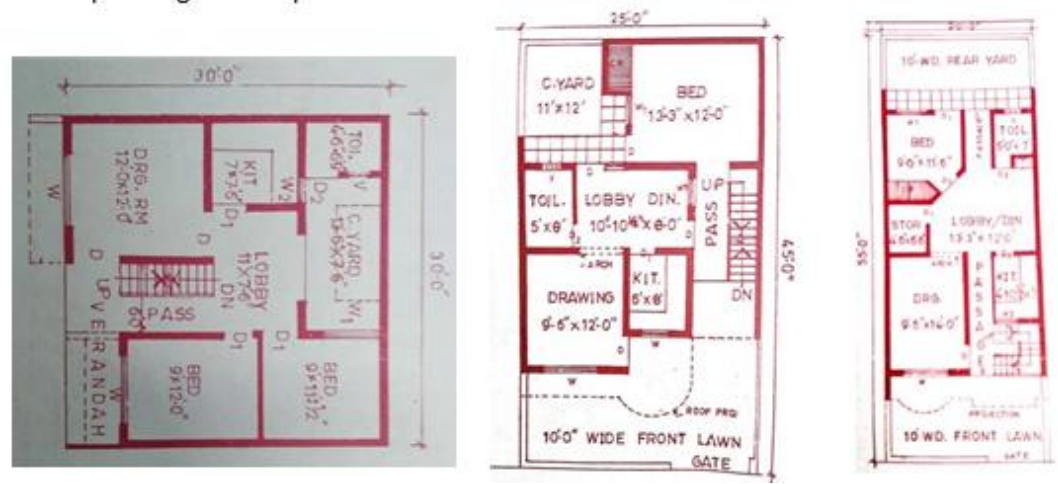

Figure 19: Architectural planning of some typical urban houses, Pakistan

In some residential units, the main entrance directly opens into the lounge and further connected to drawing, dinning, kitchen and bed rooms areas is provided considering the clearance space required for each unit of a house. The bedrooms are considered as a private space and usually exist at the back of house with a direct access from lounge or through a lobby. Every home has its own particular laundry space which exists at the back of the house and mostly semi covered and not included in the covered area. The typical and most prevalent construction of envelope components have been discussed in detail. 


\subsubsection{Wall}

Brick is the most popular material used for wall construction in residential sector of Pakistan. About $62.38 \%$ of the total built environment in rural and urban areas constitutes brick masonry house construction. Bricks are constructed with mud mortar or cement sand mortar. Brick homes give relatively cool effect because it acts as natural insulator in the climates where temperature goes up to $38-44 \mathrm{oC}$ (16) and it traps heat during the day time and dissipate at night. The walls are further finished with plaster, paints, and ornamental tile work. But in Pakistan, this construction type has resulted in poor environmental impacts due to the following reasons:

1. Poor quality construction material is being used in construction. Majority of houses are built with second and third class brick. The kiln fired, prefabricated, molded brick are considered expensive options.

2. Lack of construction guidelines and applicable building permit laws.

3. The Gravity and lateral Load-Resisting System is unreinforced masonry walls. It leads to inherent weakness in load carrying capacity of the structural system of a particular house.

\subsubsection{Roof and floor}

The roof is the most important envelope component exposed directly to heat and radiations. The covered area and the choice of insulation material affect the thermal quality of the structure. Heat gain from the roof has significant impact on the interior space temperature and thermal comfort conditions. The UN-Habitat (6) study categories insulated, reflective surface and radiant barrier techniques to improve thermal performance of RC slab roofs. The new industrial and traditional materials are readily available and affordable as environmental friendly solutions.

In urban houses, the Roof specification comes in the order of roof tiles, mud lay in slope, Insulation material, 2 coats of hot bitumen and 6 inches reinforced concrete or brick slab. The terracotta, Khaprail roof tiles are manufactured using locally available clay, under standardized conditions. There are a variety of insulating materials available in the market and with the increasing awareness of energy efficient houses in Pakistan, their use is increasing. The stabilized mud, mud with thermophore, smart concrete, Munwar AC tiles, hollow clay tiles, concrete wizard, sachal tile, and jumbolon are few famous and tested insulation materials by Enercon. The Bituminous coating or plain cement concrete (PCC 1:2:4) 2 inches thick topping are the water proofing surface treatment on the roof slabs. The Corrugated Galvanized Iron roofing (CGI) and Reinforced Cement Concrete (RCC) are the commonly used construction techniques. The roof specifications are further protected by the parapet walls, inspired from traditional brick design, screens, or wrought iron grills.

The floor specification varies on the basis of space, traffic flow, outdoor or indoor installations. In modern houses, the extensive use of marble (Botticino), chips floor, brick tiles, wood, ceramics and sometimes glazed tiles. The wooden tiles are used in the light traffic zones of bedrooms, study, and drawing areas. The 1 inch floor tiles are followed by the layers of $0.05 \mathrm{~m}$ of PCC (1:2:4), $0.10 \mathrm{~m}$ brick ballast, $0.10 \mathrm{~m}$ sand filling and well compacted earth. 


\subsubsection{Fenestration}

In order to address the natural ventilation, operable, sliding and bay windows are found in most of the colonies and societies. Single glazed uPVC (un-plasticized polyvinyl chloride), aluminium or wooden frame windows are extremely popular in residential buildings of Pakistan. There exists least information in building stakeholder about the choice of window materials regarding $\mathrm{U}$-factor and solar heat gain co-efficient requirements. Windows are mostly protected by the roof projections and horizontal shades.

\subsection{Thermal conductance requirements of envelope components}

The building energy codes of Pakistan were published in 1990 and it defines the minimum allowable thermal conductance for the envelope components. The values are never derived from the ASHRAE Standards and their validity in Pakistan climatic context is never cross checked. Unfortunately, even these requirements have also never been used in actual practice while designing and constructing houses in Pakistan.

However, the following requirement of thermal conductance U0 (watt $/ \mathrm{m} 2$ ) for five climatic zones is defined in BECP.

Table 3: Thermal conductance requirements for envelope components in BECP (8)

\begin{tabular}{|l|c|c|c|c|c|}
\hline \multirow{2}{*}{ Envelope components } & \multicolumn{5}{|c|}{$\begin{array}{c}\text { Thermal conductance } \mathrm{U}_{0}\left(\mathrm{watt} / \mathrm{m}^{2}\right) \\
\text { of climatic zones }\end{array}$} \\
\cline { 2 - 7 } & 1 & 2 & 3 & 4 & 5 \\
\hline Walls & 2.67 & 2.56 & 2.22 & 2.50 & 2.22 \\
\hline Roof/ceiling & 0.58 & 0.58 & 0.58 & 0.58 & 0.58 \\
\hline Shaded roof and floor exposed to weather & 1.16 & 1.16 & 1.16 & 1.16 & 1.16 \\
\hline Floors, unheated space & 2.27 & 1.70 & 1.42 & 1.70 & 1.42 \\
\hline Heated slab on grade & 2.27 & 1.59 & 1.35 & 1.49 & 1.35 \\
\hline
\end{tabular}

\subsection{Passive design issues}

Passive design techniques are the energy saving strategies used in buildings for achieving the thermal comfort in a particular climate. Previous studies conducted in Pakistan inadequately address the passive solutions of achieving thermal comfort in urban setting. Due to lack of awareness among the stakeholders, the implication of the passive techniques on urban residential design is missing. Unfortunately, there are very few case studies available that document both the effectiveness and the practical problems of installing a range of passive strategies specifically with reference to Pakistan (17).

Following commonly observed design issues are found in residential buildings of Pakistan:

1. Natural cross ventilation is an important strategy that can ensure lowering down of temperature. But in the modern construction of houses, either the size or the design of window does not allow the required air exchange with respect to space volume.

2. In most houses, space, volume is also not designed according to number of occupants using the space. This is particularly important in the bedroom and lounge area.

3. In most of the houses, the store is most neglected designed space and most of the 
time there is no provision of windows for space ventilation.

4. In a climate like Multan and Rahim Yar Khan where dust storms are a normal routine, either windows have not been provided or blocked to stop dust. This kind of solution has also resulted in ventilation problems.

5. Orientation issues are also quite common because of their non-consideration in designing houses. Openings, specifically south oriented windows, are not well protected from the intense solar radiations.

6. People, who can't afford air conditioning, mostly rely on air cooler to achieve thermal comfort. This solution doesn't work in extreme humid season especially in a climatic region of Multan, Karachi and Lahore.

7. Windows are not well protected to the intense solar radiation and most of the people rely on temporary solution of using "green chadar" or "chikh" to increase the cooling effect.

8. The poor material and construction quality for the thermal mass tends to quick transfer of heat through conduction.

9. In hot climatic regions, where solar radiations are very intense, the exposure to sun leads to $70 \%$ of heat transmission from the roof top. In such cases, the provision of roof insulation can be an effective solution. But unfortunately due to increased construction cost, the roof insulation is not so common.

10. The envelope components pose a major problem in summer heat gain and winter heat loss.

11. Densely populated cities with congested living spaces have worsened the situation particularly for low-income groups who have limited access to outdoor space and who cannot afford to have electrical solutions (fans and air conditioning) to maintain thermal comfort level (6).

12. There is not much awareness about the thermal conductance requirements for the envelope components that results in excessive heat transfer to the inside.

13. Use of single glazed window is quite common and leads to excessive heat transfer.

14. In order to deal with the thermal comfort requirements in Pakistan, there seems no application of solar study in any particular climate of Pakistan. The effective use and handling of solar radiations for different orientation during the hot and cold season of the year has also not yet been considered.

\subsection{Landscape design of houses}

In urban cities, the farm land trees and linear planting exists along the road. The urban houses are also improvised with the provision of front, back yard, and in some cases sidewalks also have planters. The use of various types of trees, and shrubs are commonly observed to mitigate the harsh climatic conditions. Some houses, plant their own herbs, which they use in their daily life. For vertical gardening, people also used climbers and creepers. Even urban houses have dedicated green belts, well maintained and manicured. In comparison to urban centers, rural districts have variety of vegetation and plantation in terms of available farmland.

\subsection{Thermal comfort solutions}

In order to minimize the effect of high temperature in summer, the openings are 
protected using architectural and local solutions such as:.

1. Green Neeting. ${ }^{4}$

2. Chik.. 5

3. Night sleep at roof top or in courtyard.

4. Use of air cooler in the central lounge to lower down the temperature of house

5. Whole house fan used for cooling.

\subsection{Ventilation strategies}

Ventilation is an important phenomenon for air circulation within a house. It is achieved through the use of various strategies, either natural or mechanical. The minimum operable window area for natural ventilation as proposed in BECP is defined in Table 3.

Natural ventilation is encouraged through:

1. Adequate air flow and velocity inside the house

2. Position of the openings relative to wind direction

3. Position and size of openings in adjacent or opposite walls should be carefully designed.

Table 4: Percentage area of windows for natural ventilation in various zones of a house (18)

\begin{tabular}{|l|c|}
\hline Zones & $\begin{array}{c}\text { Minimum operable } \\
\text { window area }\end{array}$ \\
\hline Residential (Bed rooms, drawing rooms, dining rooms, kitchens & $50 \%$ \\
\hline Water closet, toilet, bathroom, laundry & $100 \%$ \\
\hline Stairs, utility areas, Corridor, lobbies & $50 \%$ \\
\hline
\end{tabular}

\section{Findings}

The research summarizes its findings in the form of common and variable features of urban and rural houses. It has been found that certain features that passively contribute as energy saving measures have been observed in both rural and urban regions. These are vernacular solutions adapted as modern features of urban and rural architectural morphology. The present research has also comparatively analyze urban and rural architectural morphology and it tends to classify both on exclusive situation, where infrastructure facilities, land use pattern, architecture and urban planning, ndustrialized materials and technological comfort solutions takes into account. But the other problems of urbanization, transportation, social disconnection and environmental challenges also come into effect. Also there is a significant difference in the material used for rural and urban construction, but passive design techniques could be easily adaptable in the design of residential buildings.

${ }^{4}$ A green chadar is local solution used in hot regions of Pakistan to mitigate the direct solar radiation in order to protect the building surface. It's mostly on the openings or porch to shade from sun.

${ }^{5} \mathrm{~A}$ chikh is a kind of blind or curtain used at the openings to provide protection from solar radiations, dust and excessive light transfer. The material used for this purpose is an organic material like small bamboo sticks or straws etc. 


\subsection{Architectural morphology of traditional housing}

The architectural morphology of traditional housing is based on vernacular approaches. The use of climate responsive material and passive design together give a special character to the area. Each region has evolved a certain architectural character based on the temperature and humidity conditions. The geographical regions not only give the houses a cultural identity in their respective climates. The architectural character of Pakistan is influenced by many ancient cultures of Indus valley, Hindus, Muslims, Turco Mongols, Afghans, Sikhs, and The Great Britain. The beauty of vernacular traditions varies from place to place, adding the taste and values of local and indigenous materials and construction practices. The wide variety of construction styles have emerged due to the local culture, climatic conditions and economical living. It has resulted in sustainable and climate responsive design and construction of houses. The non-skilled habitants have found interesting and energy efficient vernacular solutions to mitigate the climate effect in a particular area. The passive solutions are providing lesson learning from past experiences (19) and positively effecting the future development in each regions. Traditional houses are based on high thermal mass and passive cooling techniques. Thermal control in these houses is being addressed by proper architectural design based on the concept of courtyard design, natural cross ventilation and appropriate use of local materials for envelope. Each area has a strong deep rooted tradition and life style, reflected in their built structure. The design principles closely follow the climatology and respect the locally available materials based on the geographical conditions.

The following table will summarize the architectural morphology of vernacular practices, according to four regions.

Table 5: Architectural morphology of vernacular practices

\begin{tabular}{|l|l|l|}
\hline Climate & Material & Passive Design \\
\hline Highland & $\begin{array}{l}\text { Timber, stone, mud bricks, clay and soil } \\
\text { mortar }\end{array}$ & $\begin{array}{l}\text { Skylight, stair hall, light ways, } \\
\text { terraces, extended shades, Shaded } \\
\text { Verandas, portholes, courtyard }\end{array}$ \\
\hline Lowland & $\begin{array}{l}\text { Earthen materials like moulded mud or clay } \\
\text { blocks, pise, sun dried and burnt bricks, } \\
\text { kankar, white lime mortar and plaster, } \\
\text { terracotta tiles, sheesham and neem wood }\end{array}$ & $\begin{array}{l}\text { Thick walls, elongated ventilators, } \\
\text { screen geometric pattern, extended } \\
\text { porches, roof shading }\end{array}$ \\
\hline Coastal & $\begin{array}{l}\text { Mud and cement sand block, Acacia and } \\
\text { Sheesham timber frames, straw and earth } \\
\text { plaster }\end{array}$ & $\begin{array}{l}\text { High ceiling, central ridge, and } \\
\text { double slope roof, cross ventilation, } \\
\text { projected balconies, screens, lattices, } \\
\text { wind catchers }\end{array}$ \\
\hline Arid & $\begin{array}{l}\text { Granite rocks and crystalline rocks, straw, } \\
\text { stone and timber }\end{array}$ & $\begin{array}{l}\text { Ventilators, thatched roofs, } \\
\text { traditional ponds and wells }\end{array}$ \\
\hline
\end{tabular}

In rural area local needs, local materials, and local traditions are manifested in vernacular architecture. The existence of traditional design practices based on vernacular approach is also a source of lesson learning from the past. The exemplary approaches of environmental responsive design in buildings are a solution to the climate change and global warming. 


\subsection{Architectural morphology of Urban houses}

In Pakistan, there is a social trend of owning personal houses therefore the residential building trend of 1-2 stories houses dominates over the apartment housing. According to the findings of the Pakistan Federal Bureau of Statistics, 90\% of Pakistanis live in their own houses and approximately $70 \%$ houses in Pakistan have 2-4 rooms (20). Currently residential buildings are designed with little focus on climatic conditions and urban characteristics. The houses in Pakistan are dependent on electricity for addressing the daily energy demands (21). Most of the electricity is consumed for improving the comfort conditions and to overcome severe weather conditions within urban communities. The design of urban housing lacks the consideration of passive design strategies such as shading, orientation, thermal mass, natural lighting and ventilation etc. The building consumes more energy for space heating and cooling because of architectural planning issues and inappropriate design strategies. In most housing schemes, it is difficult to give a consideration to the envelope's solar exposure and orientation design. The poor urban planning and inefficient architectural design has led to the increased dependence on electrical appliances to address the heating and cooling requirements. Air conditioners fed on electricity are used for achieving the thermal comfort conditions. Natural gas is used as the main fuel for heating purposes including cooking, space heating and hot water supply. The industrialized materials are being used for the envelope in the domestic construction of houses. Howeve, there exist a considerable variety of materials used in constructing houses across the country.

Table 6: Frequently used envelope materials in Pakistan (18)

\begin{tabular}{|c|c|c|}
\hline $\begin{array}{l}\text { Envelope } \\
\text { component }\end{array}$ & Structural component & Insulation materials (22) \\
\hline Wall & $\begin{array}{l}\text { 1. Brick } \\
\text { 2. Mud } \\
\text { 3. Cement block }\end{array}$ & \multirow{3}{*}{$\begin{array}{l}\text { 1. Glass wool } \\
\text { 2. Expanded polystyrene }(25,40,50 \mathrm{~mm}) \\
\text { - Molded beads } \\
\text { - Extruded } \\
\text { 3. Expanded polyurethane }(25,40,50 \mathrm{~mm}) \\
\text { - Molded beads } \\
\text { - extruded } \\
\text { 4. Vacuum insulation panel (VIP) }\end{array}$} \\
\hline Roof & $\begin{array}{l}\text { 1. T-iron guarder (girder) } \\
\text { 2. Wood } \\
\text { 3. Sarkanda/Sirkiyan } \\
\text { 4. Concrete }\end{array}$ & \\
\hline Floor & $\begin{array}{l}\text { 1. Mud } \\
\text { 2. Cement } \\
\text { 3. Tiles } \\
\text { 4. Chips } \\
\text { 5. Brick } \\
\text { 6. Marble }\end{array}$ & \\
\hline Fenestration & $\begin{array}{l}\text { Single pane with frame } \\
\text { (wood, vinyl, fiberglass, } \\
\text { metal like aluminium } \\
\text { frames) }\end{array}$ & $\begin{array}{l}\text { Double glazed with } \\
\text { 1. Low thermal conductivity gas fill } \\
\text { 2. Electro chromic glazing } \\
\text { 3. Holographic optical elements } \\
\text { 4. Aerogel glazing } \\
\text { 5. Spectrally selective glass coatings (low E) }\end{array}$ \\
\hline
\end{tabular}




\section{Energy Saving measures}

There are some passive design features that are adapted in urban houses from vernacular approaches. The research identifies four potential features that have the ability to optimize energy in urban houses. The morphology of these features are similar in architectural design and will help in energy saving e.g: stair hall adapted from Barsati6, sun shading devices, clerestory windows, courtyards and social spaces.

\subsection{Stair hall/ Barsati}

In order to increase the air movement for warm, humid and monsoon seasons, a special feature of Barsati help in the circulation of air movement. A barsati is a three sided enclosure, with an opening on one side, connected to the stair case. It also helps to store charpaies7, that helps in outdoor sleeping, other common features of rural and old urban houses. The room also has window screens at the height of above Gfeet to keep privacy with the nearby neighbourhood.

In modern urban houses, the similar feature is modified as stair hall that connects the two or more floors in a single house. But in urban houses, it's an enclosure of room, with walls on all four sides and windows for ventilation or sometimes a large window is also provided to increase the daylight. Its purpose is merely an aesthetic element on the exterior side to break the monotony of facades. In some houses, the staircase is part of lounge, used as interior design features, incorporating wood work with a storage cabinet.

\subsection{Sun shading devices}

Sun shading devices are the predominant feature of envelope used in high, lowland, coastal and arid region. The design of openings focuses on wall to window ratio, which is further linked with the space volumes for which required air change. Deep loggias, projected balconies, deep overhangs are the sun shading devices used to overcome the heat penetration and cut the solar glare caused by sun. They not only protect in summers, but also allow winter sun to pass through the openings. These devices helps in air movement with the provision of geometric lattice structure of brick, cement, wood and marble balconies. These screens mitigate the effect of hot air when strikes on their surface to give the cool breeze to the indoor. Wood, concrete and terracotta lattices increase the indoor comfort when air passes through the narrow holes of screens, improving the air quality and reduces air temperature.

Perforated screen also acts as a sun shading device to purify air and cut glare. In old walled city houses of Punjab, the perforated designs of brick are used as screens in the walls and windows. These screen acts as sun shading devices in summers and perforation creates a beautiful silhouette pattern of sunlight, that filter sun through openings in winter season. There is a large variety of designs inspired from the traditional geometric pattern of Mughal, Anglo Indian, and Islamic in rural areas.

\footnotetext{
${ }^{6}$ Barsati is a stairhall used in urban and walled city houses.

${ }^{7}$ Charpai is a bedstead of woven webbing or hemp stretched on a wooden frame on four legs
} 


\subsection{Courtyard}

Courtyard is one of the most efficient, effectively applicable passive design features, commonly observed in traditional residential buildings, rural and modern houses. It exists in a large variety with front, back, three or four sided open space, increasing the air flow within the buildings.

In walled city houses and in rural dwellings, a central courtyard is provided with rooms on all four sides. The courtyard is beneficial for winter sun and also help in increasing air circulation and cross ventilation of adjoined spaces. The feature is also coupled with verandas to create buffer zones between interior and exterior. The efficiency of courtyard space is further enhanced by using shading devices and landscape design. Verandas and arcades are buffer zones in courtyard, patio and open spaces to enhance the air flow within a house. The courtyard is the most renowned features of rural area and adapted in urban settings.

\subsection{Clerestory windows}

The old traditional places in coastal region have high ceiling and is featured with clerestory windows. The windows are used in large halls of lounge, drawing dinning. It allows the hot air to rise and escape, and cool air takes its place, creating an air current within the space to keep it cool in summers. The provision of Clerestory windows reduces the need for electrical lighting. The natural ventilation and light illumination will enhance in urban houses, if properly oriented according to solar direction.

\subsection{Social Spaces / Baithak}

Baithak and Mehmann khana are the places of social gathering in rural areas. Rural people socially interact in Baithak during the early morning and evening of summer and during mid noon in winters. They are open yard with trees as shelter, occupying with charpaies. The Bathak in the rural houses are peripheral enclosure that serves the same purpose of guest sitting, commonly observed in the old houses of the walled city. The concept was furthered adopted in modern houses for porches as extended shading of the roof. Additionally, urban houses have sun spaces, front and back terraces, extensively used as social gathering in modern houses. The suitable orientation of houses can help cross ventilation to take maximum advantages of prevailing wind and breeze.

\section{Conclusion}

The traditional vernacular architecture in all four geographical regions was based on open areas, construction techniques and traditional materials with higher resistance against extreme climate due to specific material properties. Now the conventional materials have been replaced by cement concrete block walls, kiln fired bricks and reinforced cement concrete roofs. The current architectural planning in residential communities is based on 1-2 story houses with bylaws planning based on the plot size. Most people in Pakistan live in a joint family system.

The variation of urban and rural housing depends on the lifestyle, living standard, the available materials and techniques. The urban centres are accessible to the different infra structure facilities like water, electricity, gas, road network, education, health and 
sanitation, while the rural setting are ignored in the development of such facilities. The rapid construction requirements in urban areas are the product of industrialization, which contradict with the harmonic approach of the vernacular traditions in rural areas of Pakistan.

However, beside many differences in rural and urban areas, there is tradition of owing their own houses and according to a survey conducted by Pakistan rural household panel (20), almost $90 \%$ of people have their personal shelters, owned by families with 2-4 rooms in each dwelling. The urban areas of cosmopolitan cities like Lahore, Karachi, Multan, Faisalabad etc. are more densely populated. In urban areas, the walled city houses are denser and closely packed while, in societies, the bylaws consideration in each locality results in less compact and loose form of houses. The internal spaces between buildings are utilized to increase the air flow in envelope design.

The modern construction methods in urban houses are homogeneous design, robust construction and industrialized materials whereas the rural morphology responds to climate, vegetation growth, natural life styles, locally available materials and indigenous construction techniques. The vernacular architecture of rural area respects the cultural expression and celebrates the diversity in regionalism. The paper is just a glimpse of the traditional and modern urban housing situation. Currently, there are lot many development and expansion at city periphery. The traditional and vernacular approaches can be combined with modern technology to provide optimized, natural solution to the environmental problems.

\section{References}

Santamouris M, Kolokotsa D. Urban climate mitigation techniques. Urban Climate Mitigation Techniques. 2016.

U.S. EIA. Residential Energy Consumption Survey (RECS), Consumption \& Expenditures Tables, U.S. Energy Information Administration [Internet]. 2015 [cited 2019 Aug 15]. Available from: https://www.eia.gov/consumption/residential/

Wolfram C, Shelef O, Gertler P. How Will Energy Demand Develop in the Developing World? J Econ Perspect. 2012;26(1):119-38.

Buxton M, Carey R, Phelan K. The Role of Peri-Urban Land Use Planning in Resilient Urban Agriculture: A Case Study of Melbourne, Australia. 2016. 153-170 p.

Thorbeck D, Troughton J. Connecting Urban and Rural Futures Through Rural Design. In 2016.

UN-Habitat. Energy efficient housing, Improvemnt of thermal performance of RC slab roofs. Vol. 69, Islamabad, Pakistan. Islamabad; 2010.

Works $\mathrm{M}$ of $\mathrm{H}$ and. National Housing Policy [Internet]. 2001. Available from: http://mohw.gov.pk/mohw/userfiles1/file/National Housing Policy.pdf

Energy N, Centre C. Draft National Energy Conservation Centre (Enercon ). Pakistan; 2011 p. 1-64.

Hughes R. Cator and Cribbage Construction of Northern Pakistan. In: Proceedings of the International Conference on the Seismic Performance of Traditional Buildings, Istanbul, Turkey . 2000.

NGO SLEW KEE. EFFECT OF COCONUT FIBER AND EGG ALBUMEN IN MORTAR FOR GREENER ENVIRONMENT NGO SLEW KEE A report submitted in partial fulfillment of the requirements for the award of the degree of Bachelor of civil Engineering Faculty of Civil Engineering and Earth Resour [Internet]. Universiti Malaysia Pahang; 2010. Available from: https://core.ac.uk/download/pdf/159178661.pdf

Khān MK. Traditional Forms of Rural Habitat in Pakistan [Internet]. 1998. Available from: http://opac.nebis.ch/F/H1LX3NCB1T6HD8JPDDGNSXY9LQPRSX6YY4UXJYKPEK1KV4 NJ94-00424? func $=$ full-set-set\&set_number $=028804 \&$ set_entry $=000003 \&$ format $=999$ 
Khan AA, Khan WA, Chaudhry AA. Mammalian diversity in thar desert habitat of Tharparkar District, Sindh, Pakistan. Pak J Zool. 2015;

Shah SU, Iqbal J. Spatial-temporal variations of vegetation and drought severity across Tharparkar, Pakistan, using remote sensing-derived indices. J Appl Remote Sens. 2016;

Enercon. Pakistan Solar Architecture (A selection of energy efficient house designs). Islamabad; 1994.

Enercon. Sectoral Energy Conservatiion Measures REPORT ON ENERGY CONSERVATION GUIDELINES AND FOLLOW-UP IMPLEMENTATION ACTIONS [Internet]. Available from: http://www.enercon.gov.pk/enerconca5f.html?mc_id=57

Sarosh Hashmat Lodi, Abdul Jabbar Sangi AA. World Housing Encyclopedia-Brick masonry construction in Pakistan. In Earthquake Engineering Research Institute (EERI) and International Association for Earthquake Engineering (IAEE; Available from: http://www.world-housing.net/wpcontent/uploads/2013/12/WHE-report173_letter.pdf

Hancock M, Lane G. IMPROVING THERMAL COMFORT BY PASSIVE THERMAL DESIGN : A STUDY OF THE EFFECTIVENESS AND PRACTICAL APPLICATION OF A RANGE OF STRATEGIES IN PRIMARY SCHOOLS IN PAKISTAN [Internet]. Vol. 0044. 1999. Available from:

https://assets.publishing.service.gov.uk/media/57a08d9740f0b64974001948/R6478_oda_final_c omplete_Nov4.pdf

ENERCON P. Building code of Pakistan (Energy Provision-2011) [Internet]. BEC-2011; 2013 p. 67. Available from: http://www.enercon.gov.pk/enercon115e.html?mc_id=21

Supic P. Vernacular architecture: A lesson of the past for the future. Energy Build. 1982;

Nazli H, Haider SH, Hausladen S, Sheikh AT, Shafiq H. Pakistan Rural Household Panel Survey 2012 (Round 1): Household characteristics [Internet]. Vol. 2012. 2012. Available from: http://cdm15738.contentdm.oclc.org/utils/getfile/collection/p15738coll2/id/127370/filename/ 127581.pdf

Nasir M, Tariq MS, Arif A. Residential demand for electricity in Pakistan. In: Pakistan Development Review. 2008.

UN-HABITAT. Energy Efficient Housing Improvement of Thermal Performance of RC slab Roofs. Islamabad: ENERCON, CDA, UN-HABITAT,UN; 2011. 